\title{
Efficacy of Liquid Protein Hydrolysate from Chicken Feather by Proteus sp. on Chili Plant (Capsicum annum) ${ }^{\dagger}$
}

\author{
Petchi Iyappan ${ }^{1}$, Thasmini Pravimasivam ${ }^{1}$, Monica ${ }^{1}$ \\ 1 School of Bioscience, Faculty of Medicine, Bioscience and Nursing, MAHSA University Bandar Saujana Putra, 41200, \\ Selangor, Malaysia \\ * Correspondence: Not available; \\ $\dagger$ Presented at International e-Conference on Bioengineering for Health and Environment (ICBHE 2020)
}

Received: 5.07.2020; Revised: 10.07.2020; Accepted: 12.07.2020; Published: 15.07.2020

\begin{abstract}
Huge amounts of feathers are discarded as wastage, and it has always been environmentally concerned as they are difficult to destroy. Feather establishes over $90 \%$ protein, which gives it a rigid structure. Biotechnological techniques can help to degrade the feathers and use as biofertilizer. The best strategy is by utilizing keratinase producing keratinolytic microorganisms from the poultry waste to deteriorate the feathers. The poultry sample was collected at the local poultry farm. Using skimmed milk agar, enriched proteolytic bacteria were isolated, and the colony morphology assessed. The isolated bacteria were assessed for keratinolytic ability by using carbon and nitrogen sources. Liquid protein hydrolysate (LPH) was prepared and added as fertilizer to determine the growth effect on Capsicum annum. The antibacterial and antioxidant activity was assessed. The isolated Proteus sp. from the poultry waste has the ability to disintegrate the feathers completely on the $10^{\text {th }}$ day. The enzymatic activity from Proteus sp. was observed increased with the presence of fructose $(1.435 \mathrm{U} / \mathrm{mL})$ and yeast extract $(2.045 \mathrm{U} / \mathrm{mL})$. The optimum temperature was at $40{ }^{\circ} \mathrm{C}(0.664 \mathrm{U} / \mathrm{mL}), \mathrm{pH}$ value $7(0.871 \mathrm{U} / \mathrm{mL})$, and feather concentration at $1.5 \%(1.2 \mathrm{U} / \mathrm{mL})$. LPH promoted the growth of Capsicum annum and increased total chlorophyll content $(5.7341 \mathrm{mg} / \mathrm{g})$ in test plants. The antimicrobial activity displayed that Escherichia coli is susceptible to LPH, and also increased antioxidant activity was demonstrated in the test plants. Thus, the addition of liquid protein hydrolysate exhibited that it has the capability to aid plant development.
\end{abstract}

Keywords: Feather; Proteus sp.; Capsicum annum; Escherichia coli.

(C) 2020 by the authors. This article is an open-access article distributed under the terms and conditions of the Creative Commons Attribution (CC BY) license (https://creativecommons.org/licenses/by/4.0/).

\section{Funding}

This research received no external funding.

\section{Acknowledgments}

This research has no acknowledgment.

\section{Conflicts of Interest}

The authors declare no conflict of interest. 